\title{
Prevalence of anaemia and undernutrition among street children in Mysuru, India
}

\author{
*K Jagadish Kumar ${ }^{1}$, K B Chethak ${ }^{1}$, H V Rama ${ }^{2}$, H R Bhaktavatsala ${ }^{1}$, V Vikash ${ }^{1}$
}

Sri Lanka Journal of Child Health, 2017; 46: 44-47

\begin{abstract}
Objectives: To assess the haemoglobin levels and nutritional status of the street children in Mysuru.
\end{abstract}

Method: In this prospective study, 204 street children were recruited. Clinical examination was done and haemoglobin was estimated with the cyanmethaemoglobin method. Classification of anaemia and undernutrition was done according to WHO criteria.

Results: Anaemia was noted in $52.5 \%$ children and $62.6 \%$ of these anaemic children had moderate anaemia. Prevalence of underweight, stunting and wasting was $76.5 \%, 36.8 \%$ and $52 \%$ respectively.

Conclusion: Of the street children in Mysuru, $52.5 \%$ had anaemia, $76.5 \%$ were underweight, $36.8 \%$ had stunting and $52 \%$ had wasting according to WHO criteria.

DOI: http://dx.doi.org/10.4038/sljch.v46i1. 8105

(Key Words: Street children, undernutrition, anaemia)

\section{Introduction}

Children must be cared, nurtured and educated properly to promote the progress of the nation. Some of the unfortunate children lack parental upbringing and support and grow in street as street children. Often they meet with a harsh physical and psychological environment making them vulnerable for many health infirmities ${ }^{1,2}$.

\begin{tabular}{l}
\hline${ }^{1}$ Department of Paediatrics, ${ }^{2}$ Department of \\
Community Medicine Jagadguru Sri \\
Shivarathreeshwara (JSS) Medical College, \\
Mysore, India \\
${ }^{*}$ Correspondence: jagdishmandya@gmail.com \\
(Received on 07 April 2016: Accepted after \\
revision on 12 June 2016) \\
The authors declare that there are no conflicts of \\
interest \\
Personal funding was used in formulating the \\
article. \\
Open Access Article published under the Creative \\
Commons Attribution CC-BY CC)
\end{tabular}

Unfortunately, problems of street children are growing at an alarming speed throughout the world ${ }^{3,4}$. It is very difficult to estimate the exact number of street children throughout the world, but the number is likely to be as high as 100 million ${ }^{4,5,6}$. India accounts for $10 \%$ of the world street children 5 . In India, around $63 \%$ of children go to bed hungry and $53 \%$ suffer from chronic malnutrition, which reflects the poor status of children in general ${ }^{1}$. Little is known about the health and nutritional status of street children. Anaemia is the common treatable problem which can lead to intellectual and cognitive dysfunctions in children ${ }^{7}$ Most of the studies reported anaemia on clinical grounds not on estimation of haemoglobin levels ${ }^{4,8,9}$.

\section{Objective}

The main objective of this study was to estimate the haemoglobin levels and to asses nutrition of street children in Mysore city.

\section{Method}

This prospective, cross sectional descriptive study was conducted in the city of Mysuru, Karnataka State, India. For this study a convenient sample size of 204 street children were enrolled. Ethical approval was obtained from Jagadguru Sri Shivarathreeshwara Medical College, Mysuru Ethical Committee. Consent was obtained from the District Block Education Officer, Sarva Shikshana Abhiyana Programme and Officer in Charge for Street Children, Non-Governmental Organisation (NGO), Mysuru. Information about the age of the child was collected from the caretakers of the children (NGO/guardians/parents). Informed consent was also obtained from the individual subjects. A detailed clinical examination was followed by anthropometric measurement. Weight was measured with a portable scale and height was measured using a stadiometer in standing position. All the observations were recorded in a predesigned case report form. Classification of various degrees of anaemia and undernutrition was done according to World Health Organization (WHO) criteria ${ }^{10,11}$. Prevalence of malnutrition (underweight, stunting and wasting,) by age and sex classification was based on WHO reference curves. The height and weight of each child was 
compared with the WHO child growth standards for that particular age and sex to get weight for age, height for age and weight for height indices. Children below two standard deviations (2SD) of the reference median on any of these indices were considered as malnourished and termed as underweight, stunted and wasted respectively. Haemoglobin was estimated by the cyanhaemoglobin method.

All data obtained were entered in MS excel sheet, analysed and interpreted in terms of mean, SD and percentages as appropriate. SPSS version 22 was used for further analysis like Chi-square test / Ztest for difference between proportions. The association and differences were interpreted to be statistically significant at $\mathrm{p}<0.05$.

\section{Results}

Of 204 children, 158 (77.5\%) were males. There were $178(87.2 \%)$ children in the age group of 7-16 years. Prevalence of underweight, stunting and wasting according to age and sex among the street children is shown in Table 1.

Table 1: Prevalence of underweight, stunting and wasting according to age and sex among street children

\begin{tabular}{|c|c|c|c|c|c|c|c|}
\hline \multirow[t]{2}{*}{ Category } & \multirow{2}{*}{$\begin{array}{l}\begin{array}{l}\text { Number of } \\
\text { children }(\%)\end{array} \\
\end{array}$} & \multicolumn{2}{|c|}{ Undernutrition } & \multicolumn{2}{|c|}{ Wasting } & \multicolumn{2}{|c|}{ Stunting } \\
\hline & & \multicolumn{2}{|c|}{ Present Absent } & \multicolumn{2}{|c|}{ Present Absent } & \multicolumn{2}{|c|}{ Present Absent } \\
\hline Age (Years) & & & & & & & \\
\hline Less than 7 & $26(13.0)$ & $18(69.2 \%)$ & $08(30.8 \%)$ & $09(34.6 \%)$ & $17(65.4 \%)$ & $12(46.2 \%)$ & $14(53.8 \%)$ \\
\hline $7-10$ & $83(40.5)$ & $63(75.9 \%)$ & $20(24.1 \%)$ & $40(48.2 \%)$ & $43(51.8 \%)$ & $20(24.1 \%)$ & $63(75.9 \%)$ \\
\hline $11-16$ & 95 (46.5) & $75(78.9 \%)$ & $20(21.1 \%)$ & $57(60.0 \%)$ & $38(40.0 \%)$ & $43(45.3 \%)$ & $52(54.7 \%)$ \\
\hline Total & 204 & $156(76.5 \%)$ & $48(23.5 \%)$ & $106(52.0 \%)$ & $98(48.0 \%)$ & $75(36.8 \%)$ & $129(63.2 \%)$ \\
\hline 'P' value & - & \multicolumn{2}{|c|}{0.578} & \multicolumn{2}{|c|}{0.048} & \multicolumn{2}{|c|}{0.008} \\
\hline Sex & & & & & & & \\
\hline Male & $158(77.5)$ & $124(78.5 \%)$ & $34(21.5 \%)$ & $88(55.7 \%)$ & $70(44.3 \%)$ & $56(35.4 \%)$ & $102(64.6 \%)$ \\
\hline Female & $46(22.5)$ & $32(69.6 \%)$ & $14(30.4 \%)$ & $18(39.1 \%)$ & $28(60.9 \%)$ & $19(41.3 \%)$ & $27(58.7 \%)$ \\
\hline 'P' value & - & \multicolumn{2}{|c|}{0.146} & \multicolumn{2}{|c|}{0.035} & \multicolumn{2}{|c|}{0.289} \\
\hline
\end{tabular}

The overall prevalence of underweight, wasting and stunting in street children is $76.5 \%, 52 \%$ and $36.8 \%$ respectively (Table 1 ). Higher prevalence of underweight was seen among boys when compared to girls but this was not statistically significant $(\mathrm{p}=0.14)$. Prevalence of wasting was significantly higher in boys $(p=0.03)$. There was no significant difference in the prevalence of stunting between genders $(\mathrm{p}=0.28)($ Table 1$)$.

The WHO classification of anaemia was used ${ }^{11}$. This is as follows:

- $\quad$ Children 5-11 years of age: mild $=11.0$ $11.4 \mathrm{~g} / \mathrm{dl} ;$ moderate $=8.0-10.9 \mathrm{~g} / \mathrm{dl} ;$ severe $=$ below $8.0 \mathrm{~g} / \mathrm{dl}$.
- $\quad$ Children 12-14 years of age: mild = 11.0$11.9 \mathrm{~g} / \mathrm{dl}$; moderate $=8.0-10.9 \mathrm{~g} / \mathrm{dl}$; severe $=$ below $8.0 \mathrm{~g} / \mathrm{dl}$.

- $\quad$ Females $>15$ years: mild $=11.0-11.9 \mathrm{~g} / \mathrm{dl}$; moderate $=8.0-10.9 \mathrm{~g} / \mathrm{dl}$; severe $=$ below $8.0 \mathrm{~g} / \mathrm{dl}$.

- Males > 15 years: 11.0-12.9g/dl; moderate $=8.0-10.9 \mathrm{~g} / \mathrm{dl}$; severe $=$ below $8.0 \mathrm{~g} / \mathrm{dl}$.

Prevalence and severity of anaemia among street children according to the WHO classification is shown in Table 2.

Table 2: Prevalence and severity of anaemia among street children according to the WHO classification ${ }^{11}$.

\begin{tabular}{|c|c|c|c|c|c|c|c|}
\hline Age (years) & No. & Anaemia + & Male & Female & Mild & Moderate & Severe \\
\hline 05 & 04 & 01 & 01 & 00 & 00 & 01 & 00 \\
\hline 06 & 22 & 11 & 05 & 06 & 03 & 07 & 01 \\
\hline 07 & 17 & 06 & 04 & 02 & 02 & 04 & 00 \\
\hline 08 & 22 & 08 & 07 & 01 & 04 & 04 & 00 \\
\hline 09 & 16 & 10 & 09 & 01 & 03 & 07 & 00 \\
\hline 10 & 28 & 11 & 08 & 03 & 03 & 08 & 00 \\
\hline 11 & 19 & 12 & 10 & 02 & 06 & 06 & 00 \\
\hline 12 & 31 & 23 & 18 & 05 & 09 & 14 & 00 \\
\hline 13 & 23 & 13 & 12 & 01 & 04 & 08 & 01 \\
\hline 14 & 17 & 10 & 08 & 02 & 04 & 06 & 00 \\
\hline 15 & 04 & 02 & 01 & 01 & 00 & 02 & 00 \\
\hline 16 & 01 & 00 & 00 & 00 & 00 & 00 & 00 \\
\hline Total & 204 & $107(52.5 \%)$ & $83(52.5 \%)$ & $24(52.2 \%)$ & $38(35.5 \%)$ & $67(62.6 \%)$ & $02(01.9 \%)$ \\
\hline
\end{tabular}


All of them were Hindus. Overall $52.4 \%$ of street children were anaemic and this was seen nearly equally in both genders (males $=52.5 \%$, females $=$ $52.2 \%$ ). Majority of anaemic children were in the moderate group $(62.6 \%)$ according to WHO classification (Table 2).

\section{Discussion}

Street environment poses lots of risks and hazards leading to numerous health problems. About $72 \%$ of street children belong to 6-12 years of age group and $13 \%$ children were aged below 6 years according to $\mathrm{UNICEF}^{12}$. It is uncommon to find children below 5 years as street children ${ }^{3}$. The age of the street children in our study ranged from 5 to 16 years and $87 \%$ of them belong to the age group of 7-16 years. Several studies have shown that the majority of the street children are boys $3,4,6,8,12$. In our study, $77.5 \%$ of street children were boys. This could be attributed to increased emotional gap and conflict between parents and children at the time of puberty ${ }^{13}$. In contrast, girls work as domestic servants in houses as street life is more dangerous because they are vulnerable to sexual abuse $e^{3,4}$.

Most of the studies reported anaemia on clinical grounds not on estimation of haemoglobin levels ${ }^{4,8,9}$. Various studies reported anaemia in more than $70 \%$ of street children ${ }^{3,8,9,14,15}$. Study conducted in Beni-Suief city revealed anaemia in $86.1 \%$ of street children, who also had high prevalence of parasitic infestation which they attributed to the very high prevalence of anaemia ${ }^{3}$. Among street children in Ghana, anaemia was detected in $78 \%$ and $92 \%$ of them had parasitic infestations ${ }^{14}$. The studies from Alexandria and Cairo also observed anaemia in $78 \%$ and $73 \%$ of street children respectively ${ }^{9,15}$. In our study, prevalence of anaemia is comparatively less than the above studies. However, a study from Nepal revealed $6.2 \%$ of street children were anaemic ${ }^{4}$. Almost $47.9 \%$ children in this study consumed meat multiple times a week and this may be the reason for the low prevalence of anaemia ${ }^{4}$. In another study from Indonesia, the prevalence of anaemia was only $29.3 \%$ of street children and it was more common in females $(45.3 \%)$ compared to males $(23.4 \%)$ unlike in our study group ${ }^{16}$. Probably the difference in the prevalence of anaemia among various studies can be due to subjective difference in clinical assessment of pallor, to the parasitic infestations and the quality of the diet consumed.

Malnutrition is highly prevalent in developing and underdeveloped countries. In India, the undernutrition is noticed up to the tune of $50 \%$ in the adolescent age group ${ }^{17}$. Our study reflected the same with accentuated proportion of malnutrition in street children. This increase prevalence of malnutrition may be because of lack of good nutritious diet which is necessary for the young adolescents for their normal growth. Most of the street children around the world are malnourished and underweight ${ }^{5,6}$. Study from Kenya reported stunting in $31.1 \%$ and underweight in $41.9 \%$ of street children ${ }^{18}$. Kiwanis magazine, reported it as high as $83 \%$ in Ghana ${ }^{14}$. Rita Patrias et al from Indonesia have reported that $42.7 \%$ and $80.4 \%$ of street children were underweight and stunted respectively ${ }^{16}$. Irregular earnings, irregular availability of food and spending on health issues predispose these street children to undernutrition ${ }^{3,4}$. This is generally compounded by unhealthy lifestyles and bad habits such as smoking cigarettes, addiction to glue, or liquor $\mathrm{etc}^{16}$. A limitation of the study is that the age of the child was obtained from NGOs in some instances and this may not be very reliable.

\section{Conclusions}

Of the street children in Mysuru, 52.5\% had anaemia, $76.5 \%$ were underweight, $36.8 \%$ had stunting and $52 \%$ had wasting according to WHO criteria.

\section{Acknowledgments}

We are thankful to Dr. Siddalinga Hugar. Department of Community Medicine, JSS Medical College, Mysore for his assistance in statistical analysis.

\section{References}

1. Making health care accessible to street children. In: Fernandez N, Daruwalla N, Choure S, Tiwari K. project team. The 'Hospital on Wheels' Project (2000-2006) SNEHA. 2008. Available from: snehamumbai@snehamumbai.org

2. Patra S, Anand K. Homelessness: A hidden public health problem. Indian Journal of Public Health 2008; 52:164-70. PMid: 19189843

3. Elazim Mohamed AA, Adly Labeeb S, El Hafnawy TM, Mohamed AG. Health status and risk factors of street children in Beni-Suief City. Assiut University Bulletin for Environmental Researches 2011; 14:109-30. 
4. Thapa K, Ghatane S, Rimal SP. Health problems among the street children of Dharan municipality. Kathmandu University Medical Journal 2009; 7: 2729.

5. Street Children of India - Slumdogs Available from: www.slumdogs.org/street-children-ofindia.html

6. Improving the lives of street children. In: Pillai MV, Manoj Kumar Pattanaik MK, editors. Icfai Books. The Icfai University Press (C) 2008 Printed in India. ISBN: 97881-314-xxxx-x

7. Jauregui-Lobera I: Iron deficiency and cognitive functions. Neuropsychiatric Disease and Treatment 2014; 10:2087-95. https://doi.org/10.2147/NDT.S72491

PMid: 25419131 PMCid: PMC4235202

8. Singh D, Sareen N, Ojha A, Sareen D. Street children of Udaipur: Demographic profile and future prospects . Stud Tribes Tribals 2008; 6(2): 135-9

9. Eltahalwy EM, Schawki MM, Ghobashi MM, AUC Social Research Center. An evaluation of the health condition of street children in Cairo. Public Health and Human rights, APHA 134th Annual Meeting and Exposition; November 4-8, 2006.Boston

10. The WHO child growth standards. Available from: http://www.who.int/childgrowth/standards /Technical_report.pdf. Accessed on 12-12016

11. Haemoglobin concentrations for the diagnosis of anaemia and assessment of severity VMNIS | Vitamin and Mineral Nutrition Information System WHO/NMH/NHD/MNM/11.1. WHO home page: http://www.who.int (C) World Health Organization 2011.

12. Mgr.Beata Pietkiewicz-Pareek. Common social problems among Street Children in India.In: Advanced Research in Scientific Areas. 2012 December, Section 6. Psychology, Sociology and Pedagogy, Social Science. International Virtual Conference. Slovakia http://www.arsaconf.com. EDIS - Publishing Institution of the University of Zilina 2012.p.981-985

13. Agnihotri P. Street boys of Delhi: A study of their family and demographic characteristics. Indian Journal of Medical Science 2001; 55:543e8.

14. Pemberton S. Saving the street children. Kiwanis Magazine.2007. Indianapolis: Kiwanis International; p. 1-6.

15. Salem EM, Abdel-Latif F. Sociodemographic characteristics of street children in Alexandria. East Mediterranean Health Journal 2002; 8:64-73.

PMid: 15330562

16. Patriasih R, Widiaty I, Dewi M, Sukandar D. Nutrient intake and nutritional status of street children in Bandung. Journal of Nutrition and Food 2010; 5: 178-84.

17. Deka MK, Malhotra AK, Yadav R, Gupta S. Dietary pattern and nutritional deficiencies among urban adolescents. Journal of Family Medicine and Primary Care. 2015; 4:364-8.

https://doi.org/10.4103/2249-4863.161319

PMid: 26288775 PMCid: PMC4535096

18. Ayaya SO, Esamai FO. Health Problems of the street children in Eldoret, Kenya. East Africa Medical Journal 2001; 78: 624-9. https://doi.org/10.4314/eamj.v78i12.8930 PMid: 12199442 